\title{
MODIFICATION AND PERFORMANCE EVALUATION OF A WHEAT THRESHER
}

\author{
Ajmal U.B. ${ }^{1}$, Khan M.U. ${ }^{2,9 *}$, Faheem M. ${ }^{1}$, Tayyab M. ${ }^{3}$, Maje`ed M. ${ }^{4}$, Sarwar A. ${ }^{5,9}$, \\ Khan M.R. ${ }^{6}$, Shariati M.A. ${ }^{7}$, Shafeeque M. ${ }^{8}$, Mohamed A.M. ${ }^{9}$ \\ ${ }^{1}$ Department of Farm Machinery and Power, University of Agriculture, Pakistan \\ ${ }^{2}$ Department of Energy Systems Engineering, University of Agriculture, Pakistan \\ ${ }^{3}$ Punjab Bio Energy Institute, University of Agriculture, Pakistan \\ ${ }^{4}$ National institute of Food Science and Technology, University of Agriculture, Pakistan \\ ${ }^{5}$ Department of Irrigation and Drainage, University of Agriculture, Faisalabad, Pakistan \\ ${ }^{6}$ Institute of Soil and Environmental Sciences, University of Agriculture, Faisalabad, Pakistan \\ ${ }^{7}$ All Russian Research Institute of Phytopathology, Moscow Region, Russia \\ ${ }^{8}$ Key Lab of Ecosystem Network Observation and Modeling, Institute of Geographic Sciences \\ and Natural Resources Research, University of Chinese Academy of Sciences, China \\ ${ }^{9}$ Biological Systems Engineering, Washington State University, United States of America
}

*E-mail: muhammadusman.khan@wsu.edu

\begin{abstract}
In this study different parameters affecting the performance of wheat thresher were established. The performance of the thresher was tested at three different speeds of the cylinder $\left(S_{1}=1600 \mathrm{rpm}, S_{2}=1700 \mathrm{rpm}\right.$ and $\left.S_{3}=1800 \mathrm{rpm}\right)$, three different feed rates of the crop $\left(\mathrm{FR}_{1}=200 \mathrm{~kg} / \mathrm{h}, \mathrm{FR}_{2}=250 \mathrm{~kg} / \mathrm{h}\right.$ and $\left.\mathrm{FR}_{3}=300 \mathrm{~kg} / \mathrm{h}\right)$ and three different varieties $(\mathrm{V} 1=$ Sahar-2006, V2 = Shafaq-2006 and V3 = Lasani-2008) of the wheat crop. GLM (General Linear Model) software of SAS was used to analyze the collected data for the machine performance. The results showed that cylinder speed, feed rate and the crop variety are the important parameters which affect the performance of the thresher. The best speed for detachment of wheat grains from the ear head is $1800 \mathrm{rpm}$ at a feed rate of $200 \mathrm{~kg} / \mathrm{h}$. The best variety of crop which show minimum losses during threshing is $V_{1}$ i.e. Sahar (2006).
\end{abstract}

\section{KEY WORDS}

Thresher, grain, performance, losses, cylinder speed, feed rate.

There are about 500 agricultural machinery manufacturing units in Pakistan with capacity of 1.38 million per annum such as cultivators, sugarcane crushers, plant protection equipment, rice husking machine, wheat threshers, drills, harrows, ploughs, chaff cutters, rice hullers and rice polishing machines (Ahmad, 2004). The traditional methods which are used for seed separation from the stalks are uneconomical, laborious and time consuming. Therefore, the development of rice threshers for seed separation from the stalk has an edge over conventional methods (Chaudhry, 1979).

Threshing is one of the essential practices which can affect the quantitative and qualitative losses. A number of different size threshers have been in survival for a long time, but due to high prices of thresher and prime mover have not been adapted to a large level. Among these threshers, some are hand-held threshers and pedal operated ones. Threshing is a major aspect which is usually carried out after harvesting of grain crops (Nkama, 1992).

There are two main types of stationary threshing machines which have been developed. The machine of western design is known as "Through-Flow" thresher, because of passing stalks and ears through it. It contains of a threshing device with a pegs and a cleaning-winnowing method which is based upon shakers, sieves and centrifugal fans. In the 70s IRRI developed an axial flow thresher, which has been commonly made at local level (Sexana et al., 1971).

Threshing is still unnoticeable problem among the post-harvest losses; these losses do not merely generate negative repercussions for the farmers, but also have serious effects on the economy. Mahmoud et al (2007) examined that wheat crop is very sensitive to threshing 
operations due to the high percentage of grain that affects the total yield. They also concluded that cylinder peripheral speed, feeding rate and moisture content are main factors affecting the performance of threshing machines. The above mentioned factors directly affected the crop losses, energy requirements, and efficiency, which in return, influenced the total operational cost.

Singh et al (1992), reported that the handling of thresher efficiency, grain damage, losses and capacity has been a major challenge. This is due to the variable operating conditions and machine parameters. The grain characteristics go a great length in determining the general performance of cereal threshers. Various researchers attained success by proper adjustment of these operating conditions.

Threshing of grain crop which requires a set of processing conditions that must be achieved for appropriate threshing action through mechanical or manual operation. Stationary grain crop threshers are the threshers which use the threshing cylinders in a confined position. This type of thresher is of two types based on feeding method of the crop in to the thresher. These two methods are throughput and hold on types.

Manual threshing operation is an inappropriate method of threshing because it reduces the grain output as well as it requires high energy input. In a mechanical process of threshing, the inappropriate conditions of threshing not only affect the grains recovery from the other plant materials but it also results in high grain loss. The grain losses are measured by damage to the grain kernel and loss to the mechanical elements. Threshing is a unit operation which involves the removal of grains from the plant residues. Threshing is the most important process in grain production (Klenin et al., 1986; Olaoye et al., 2004).

Various researchers have determined the proper operating conditions for a mechanical thresher for successful threshing of grains and to minimize losses in a mechanical thresher. The key variables of interest for the researchers are crop parameters, environmental conditions and machine parameters (Olaoye et al., 2004). Olaoye and Oni (2001) investigated the effect of crop parameters on threshing efficiency of thresher in Nigeria. The results showed that mechanical properties of grains, grain size and geometrical dimensions of grains are the important parameters that can increase the separation of grains from the plant residue.

Many researchers have investigated that fan speed, cylinder speed and concave clearance are the key machine parameters that can influence the threshing efficiency of a mechanical thresher (Singh et al., 1981; Joshi et al., 1981; Ghaly, 1985; Behera et al.,1990).

However, in developed areas crop harvesting is usually done by a combine harvester, which harvests, threshes, and winnows the grain while it is still in the field. Despite the severity of post harvest losses, especially in food grains in developing countries like Pakistan, no comprehensive program has been initiated to tackle this problem. Thus tons of grains are lost at the farm level. The agricultural experts, scientists, technologists and policy makers have been engaged in devising ways and strategies for increasing wheat production. Post-harvest losses have been neglected aspect of farm profile in Pakistan, specially qualitative and quantitative losses during threshing process at farm yard. Over $4 \%$ of wheat produced in the country is lost due to inefficient farm operations, inappropriate agriculture technologies followed at the farm, village and commercial levels. Mitigation of these losses in the wake of rapidly increasing population would be a big contribution toward achieving the food self-sufficiency. Considering the above points there is a crucial need of small and efficient wheat thresher with maximum threshing and cleaning efficiency along with minimum losses and visible grain damage.

Therefore, this study has been undertaken with the purpose of determining and selecting appropriate threshing speed and feed rate for reducing grain damage and producing better quality of grain in post-harvest operations.

The study has been designed to achieve the following objectives: to improve, modify the Vogal Head Wheat Thresher; to evaluate the effect of threshing cylinder speed on wheat grain breakage and cleaning efficiency; to evaluate the effect of crop feed rate on grain breakage and cleaning efficiency. 


\section{MATERIALS AND METHODS OF RESEARCH}

This study was planned to evaluate the threshing parameters of Vogal Head Wheat Thresher and for making appropriate modifications to improve its performance in terms of threshing and cleaning efficiency. All tests were performed in University of Agriculture Faisalabad at Farm Machinery workshop. Detailed procedure of entire research work had been described in subsequent paragraphs including instruments used, test conducted and modifications made.

The testing and evaluation is the critical examination of machine. It helps in the design and development of better farm machinery and also controls the quality. Actually, evaluation of any machine details the deficiencies which remain present in the performance, components durability, and safety of the machine (Yasin and Ansari, 1981).

Vogal head plant thresher machine has been purchased by the University of Agriculture Faisalabad from USA. The purpose of this study was to evaluate the performance of Vogal head plant thresher and modify if needed for wheat crop during wheat harvesting season 2012. In order to meet the objectives of present research the work was conducted in Agricultural Engineering work shop. The specifications of thresher have been shown in the Table 1 and view of thresher in Figure 1.

Table 1 - Specifications of Vogal Head Wheat Thresher

\begin{tabular}{|l|l|}
\hline \multicolumn{1}{|c|}{ Item } & \multicolumn{1}{c|}{ Specifications } \\
\hline Name & Vogal Head Wheat Threasher \\
\hline Type of Thresher & Transverse Flow \\
\hline Type of Threshing Drum & Spike Tooth \\
\hline Drum Diameter $(\mathrm{cm})$ & 32.5 \\
\hline Drum Length(cm) & 55.8 \\
\hline Number of Spikes & 75 \\
\hline Number of spike Rows & 10 \\
\hline Spike upper width(cm) & 3.2 \\
\hline Spike lower width $(\mathrm{cm})$ & 1.3 \\
\hline Spike Height(cm) & 5.1 \\
\hline Concave Length(cm) & 63.5 \\
\hline Engine Type & Self-propelled petrol engine \\
\hline & Over All Dimension \\
\hline Length $(\mathrm{cm})$ & 274.3 \\
\hline Width $(\mathrm{cm})$ & 168 \\
\hline Height(cm) & 213.4 \\
\hline
\end{tabular}

The purpose of this study was to evaluate the performance of Vogal head thresher for wheat crop during wheat harvesting season 2012. Detail description of various part of the thresher is described as under with pictorial view.

Feeding Hopper. The function of the feeding unit is to feed the crop into the threshing unit for threshing. Main purpose of the feeding unit is to minimize initial grain losses and grip the crop bundle. It helps to feed the crop at uniform rate for threshing.

Threshing Unit. In this unit threshing of wheat takes place. It consists of threshing cylinder and concave which are used to thresh the wheat. Threshing cylinder consist of 75 spikes arranged in 10 rows. The crop is rubbed by spikes against the concave in such a way that no damage of grains takes place.

Concave sieve. Concave sieve was made of $6 * 9 \mathrm{~mm}$ rectangular MS bars used to separate the threshed material. The major function of sieve was to separate the grain from unwanted foreign material like straw pieces and grains other than wheat grains.

Pully. V-belt type pullies were used to transfer power from engine to all other parts, where it is required to perform the threshing, cleaning and separation actions. It was made of cast steel material. Power was shifted thorough the rubber belts.

Main Frame. It was main structural part of thresher on which all the accessories are attached. This part was strong enough to wear the weight, shocks and working stresses of all 
the parts. Two wheels were used to move from place to place it. It was made of MS angle and MS sheet formed channel.

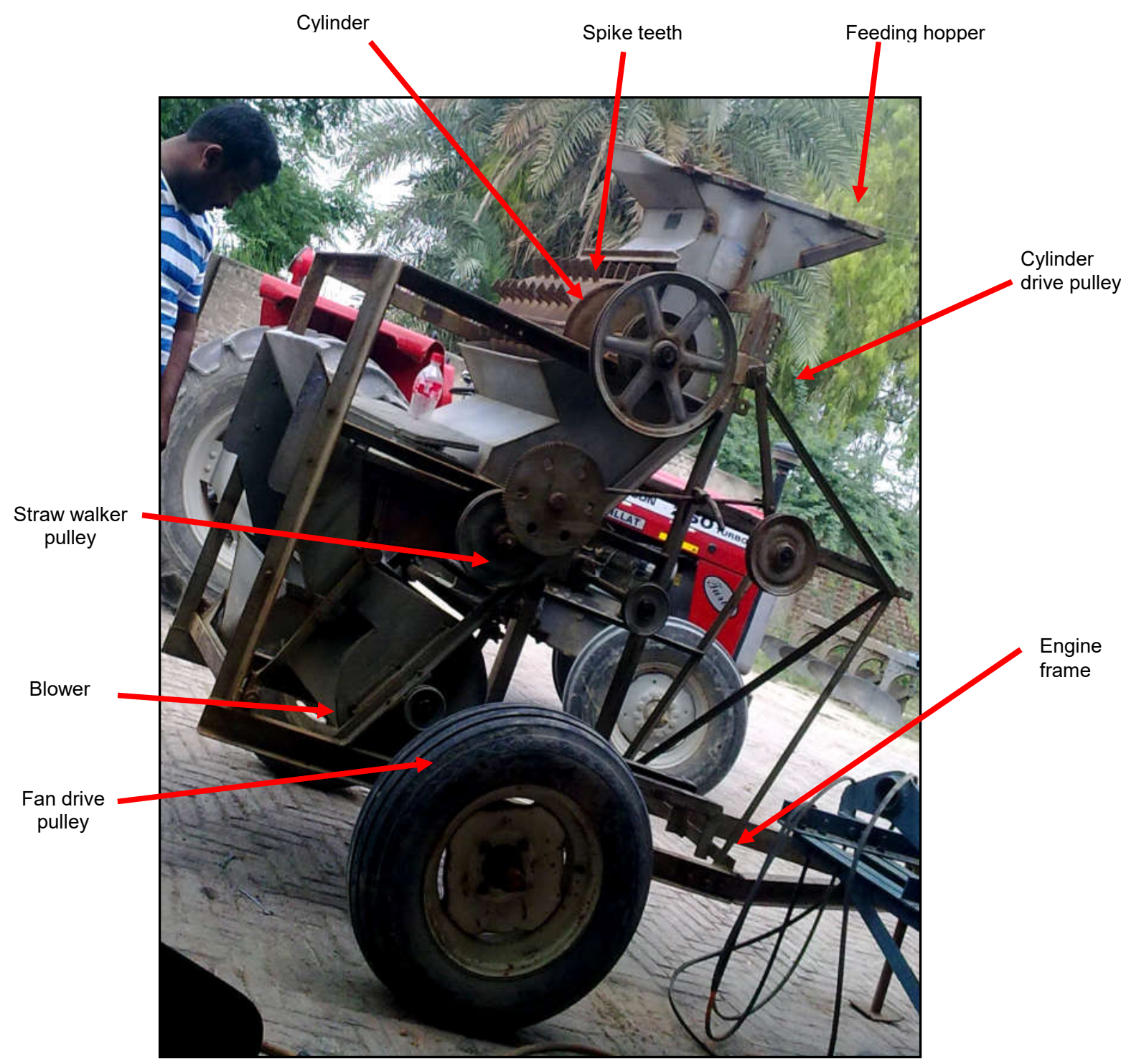

Figure 1 - Vogal Head Wheat Thresher

Cleaning Unit. The purpose of cleaning unit is to remove the straw, weeds and any other foreign material from grains. In this thresher there was no sieve so the grains were not properly cleaned. A sieve was designed in the workshop of agricultural engineering and fixed in front of air blower to enhance the cleaning efficiency of machine. The Sieve has been made of $1.25 \mathrm{~mm}$ thick stainless steel sheet of sieve hole $4.5 \mathrm{~mm}$. Average geometric mean diameter of wheat was determined as $3.8 \mathrm{~mm}$ by the following procedure explained by (Song and Litchfield 1991). This sieve allows only the gains to pass through it and any foreign material retain on the sieve while the blast of air blows out the finer chaff:

$$
D g=\left(a^{*} b^{*} c\right)^{1 / 3},
$$

Where: $\mathrm{Dg}=$ Geometric Mean Diameter of seed in $\mathrm{mm} ; \mathrm{a}=$ Length of seed in $\mathrm{mm} ; \mathrm{b}=$ Width of seed in $\mathrm{mm} ; \mathrm{c}=$ Thickness of seed in $\mathrm{mm}$.

Blower. This is an important part of thresher used to separate chaff from grains. The four blades of fan were made of wooden material which did not properly supply the desired air velocity $(\mathrm{m} / \mathrm{s})$ for grain straw separation. To overcome this problem earlier wooden blade 
were replaced with $3 \mathrm{~mm}$ mild steel sheet and installed at an angle of $90^{\circ}$. Blower fan air velocity was determined by using air flow measuring apparatus. Improved radial centrifugal fan provided required air velocity $(6-11 \mathrm{~m} / \mathrm{s})$ separating grain from straw. Air terminal velocity of grain and straw were found $8 \mathrm{~m} / \mathrm{s}$ and $4 \mathrm{~m} / \mathrm{s}$ which were measured by using the procedure explained by (Song and Litchfield, 1991).

Table 2 - Modified/Redesigned Parts of Vogal Head Plant Thresher

\begin{tabular}{|c|c|c|c|c|}
\hline $\begin{array}{c}\text { Sr. } \\
\text { No. }\end{array}$ & Part & $\begin{array}{c}\text { Original } \\
\text { Specification }\end{array}$ & Improved Specification & Remarks \\
\hline 1 & Sieve & There was no sieve & $\begin{array}{c}\text { The sieve has been made of } \\
1.25 \mathrm{~mm} \text { thick stainless sheet } \\
\text { having: Length }=63.5 \mathrm{~cm}, \\
\text { Width }=25.4 \mathrm{~cm}, \\
\text { Hole Size }=4.5 \mathrm{~mm}(\mathrm{dia})\end{array}$ & $\begin{array}{c}\text { To increase cleaning } \\
\text { efficiency and reduce gain } \\
\text { losses in straw }\end{array}$ \\
\hline 2 & Blower & $\begin{array}{c}\text { The fan fins of blower were } \\
\text { made of Wooden Material }\end{array}$ & $\begin{array}{c}\text { Wooden fan fins of blades are } \\
\text { replaced with 3 mm mild steel } \\
\text { sheet }\end{array}$ & To supply desired air velocity \\
\hline
\end{tabular}

Data Collection Procedure. Three crop varieties $\left(V_{1}=\right.$ Sahar-2006, $V_{2}=$ Shafaq-2006 and $V_{3}=$ Lasani-2008) were selected for threshing by Vogal head thresher after harvesting, the crop was tied in $15 \mathrm{~kg}$ bundles and store in the storage of Agricultural Engineering workshop. After pretesting and redesigning the parts of thresher, the thresher was operated at three different speeds $\left(S_{1}=1600 \mathrm{rpm}, S_{2}=1700 \mathrm{rpm}\right.$ and $\left.S_{3}=1800 \mathrm{rpm}\right)$ and crop fed at three selective feed rates $\left(F R_{1}=200 \mathrm{~kg} / \mathrm{h}, \mathrm{FR}_{2}=250 \mathrm{~kg} / \mathrm{h}\right.$ and $\left.\mathrm{FR}_{3}=300 \mathrm{~kg} / \mathrm{h}\right)$ the regarding threshing efficiency, grain cleaning and gain breakage was collected. All the treatment was replicated three times. The schematic design of data collection has been given in Figure 2.
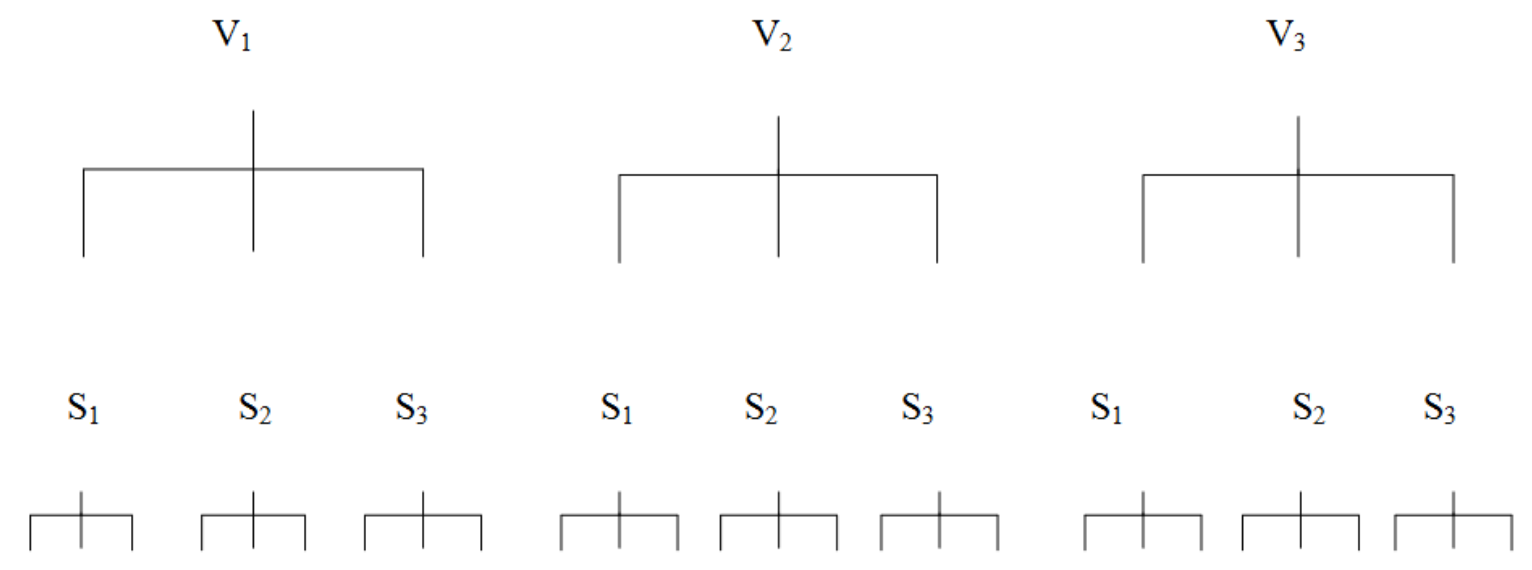

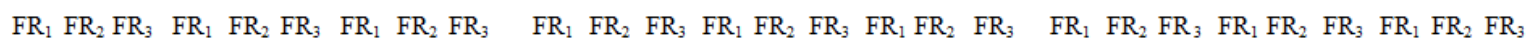

$\mathrm{V}=$ Wheat Variety

$\mathrm{S}=$ Cylinder Speed, rpm

$\mathrm{FR}=$ Feed Rate, $\mathrm{kg} / \mathrm{h}$

$V^{*}=r w=r(2 \pi s / 60)$

Linear velocities at the tip of cylinder $(27.13 \mathrm{~m} / \mathrm{s}, 28.83 \mathrm{~m} / \mathrm{s}$ and $30.52 \mathrm{~m} / \mathrm{s})$

Figure 2 - Schematic Diagram of Data Collection

A measuring tape, stop watch, tachometer and digital balance were used for different measurement during the experiment.

Pre-Test Observations. The power requirements of different functional parts of thresher were determined under load and no load conditions at three different speeds of the thresher cylinder. The cylinder concave clearance was kept constant during whole test.

Feed Rate. Feed rate is very important machine parameter that affects the threshing capacity, cleaning efficiency, grain breakage, grain loss with straw. It was determined by 
taking wheat crop bundles of three different weights $(5 \mathrm{~kg}, 10 \mathrm{~kg}$, and $15 \mathrm{~kg}$ ) and then fed into the threshing unit of the thresher for known time. Feed rate was found as follows (Ukatua, 2006):

$$
F R=Q m f / T
$$

Where: FR=Feed Rate, $\mathrm{kg} / \mathrm{h} ; \mathrm{Qmf}=$ quantity of crop material fed into the thresher, $\mathrm{kg}$; $\mathrm{T}=$ feed time, $\mathrm{h}$.

Threshing Efficiency. Threshing efficiency is an important factor with respect to machine efficiency. It was determined by taking three samples of threshed grains, Weight of each sample was measured. Un-threshed grains were separated and the samples were weighed again. Threshing efficiency was determined by applying following equation (Mahmoud et al, 2007):

$$
\text { Threshing efficiency, }(\%)=[(T G-U n G) / T G] \times 100,
$$

Where: TE $=$ Threshing efficiency, \%; UnG = Weight of un-threshed grains in the sample, g; $\mathrm{TG}=$ Weight of total grains in the sample, $\mathrm{g}$.

Un-threshed Grain Losses. Un-threshed grain is an important factor to estimate the machine efficiency. It was determined by taking three samples of threshed grains, Weight of each sample was measured. Un-threshed grains were separated and the samples were weighed again. Un-threshed grain losses percentage was calculated as following (Mishram and Desta, 1990):

$$
U G L,(\%)=\left[U n_{G} / T_{G}\right] \times 100,
$$

Where: UGL $=$ Un-threshed grain losses, $(\%) ; U n_{G}=$ Weight of un-threshed grains in the sample, $g ; T_{G}=$ Weight of total grains in the sample, $g$.

Damaged Grain Losses. All the grains are required to be in their original form as the broken grains are more liable for the attack of insects or pests. Three samples of threshed grain were taken and weighed. The damaged/broken grains were separated and weighed. The grain damage grain losses were calculated using following equation (Mishram and Desta, 1990):

$$
D G L,(\%)=\left[D_{G} / T_{G}\right] \times 100,
$$

Where: $D G L=$ Damage grains losses, $\% ; D_{G}=$ Weight of damaged grains in the sample, $g$; $T_{G}=$ Weight of total grains of the sample, $\mathrm{g}$.

Cleaning Efficiency. Cleaning efficiency is an important factor because of its value addition with respect to machinery. It was determined by taking three samples of threshed grains. Weight of each sample was measured. All the materials other than clean grains (MOG) were separated and the samples were weighed again. The cleaning efficiency was found using following equation (Ukatua, 2006):

$$
\text { Cleaning efficiency, }(\%)=\left[W / W_{O}\right] \times 100,
$$

Where: $C_{=}=$Cleaning efficiency, $\% ; W=$ Weight of unwanted material from sample, $g$; $\mathrm{W}_{\mathrm{O}}=$ Weight of sample, $\mathrm{g}$.

Grain Loss in Straw. This is the important machine parameter of a thresher which shows that how much grains losses in straw. It was determined by taking three samples of chaff coming out in known time during threshing the wheat crop material (Ukatua, 2006). All grains were separated and weighed which were throwing out with chaff. Grain loss was determined as following:

$$
G L S=W_{g s} / G F R \times 100,
$$


Where: GLS= Grain loss in Straw, \%; $W_{g s}=$ Weight of grain in straw, $g / m i n ; G F R=$ Grain feed rate, g/min; GFR = FR (1 + 1/GSR); GSR = grain straw ratio.

Grain Straw Ratio. A known weight of harvested wheat bundle of each crop variety was manually threshed using sticks. Grains and straw were separated. Collected grain and straw were weighed separately and grain straw ratio was determined as follows:

$G S R=W g / W s$,

Where: $G S R=G r a i n$ straw ratio; $W g=$ weight of grain, $\mathrm{kg}$; Ws=weight of straw, $\mathrm{kg}$.

Total Grain Losses. The total threshing losses percentage (TGL) including both unthreshed grain losses (UGL), damage grain losses (DGL) and grain losses in straw (GLS) were calculated for Vogal head plant thresher using the following equation, (Mishram and Desta, 1990):

$$
T G L,(\%)=U G L+D G L+G L S,
$$

Where: $\mathrm{TGL}=$ Total Grain Losses, kg; $\mathrm{DGL}=$ Percent of damaged grain losses, \%; UGL = Percent of un-threshed grain losses, \%; GLs = Percent of Grian losses in straw, \%.

Statistical Analysis. Statistical test was done using GLM (General Linear Model) software of SAS (SAS, 2009).

Table 3 - Treatments of the Experiment

\begin{tabular}{|c|c|}
\hline Parameters & Levels \\
\hline \multirow{2}{*}{ Cylinder speed (S) } & $3-\mathrm{S} 1=1600 \mathrm{rpm}$ \\
& $\mathrm{S} 2=1700 \mathrm{rpm}$ \\
& $\mathrm{S} 3=1800 \mathrm{rpm}$ \\
\hline \multirow{2}{*}{ Wheat variety (V) } & $3-\mathrm{V} 1=$ Sehar-2006 \\
& $\mathrm{V} 2=$ Shafaq-2006 \\
& $\mathrm{V} 3=$ Lasani-2008 \\
\hline \multirow{2}{*}{ Feed rate (FR) } & $3-\mathrm{FR} 1=200 \mathrm{~kg} / \mathrm{h}$ \\
& $\mathrm{FR} 2=250 \mathrm{~kg} / \mathrm{h}$ \\
& $\mathrm{FR} 3=300 \mathrm{~kg} / \mathrm{h}$ \\
\hline Replication (R) & $\mathrm{R} 1, \mathrm{R} 2, \mathrm{R} 3$ \\
\hline
\end{tabular}

A $3 \times 3 \times 3$ factor factorial was employed in CRD statistical design to explore the effects of three varieties $\left(V_{1}=\right.$ Sahar-2006, $V_{2}=$ Shafaq-2006 and $V_{3}=$ Lasani-2008), three cylinder speeds $(\mathrm{S} 1=1600 \mathrm{rpm}, \mathrm{S} 2=1700 \mathrm{rpm}$ and $\mathrm{S} 3=1800 \mathrm{rpm})$ and three feed rates $(\mathrm{FR} 1=200$ $\mathrm{kg} / \mathrm{h}, \mathrm{FR} 2=250 \mathrm{~kg} / \mathrm{h}$ and FR3 $=300 \mathrm{~kg} / \mathrm{h}$ ) on threshing efficiency, wheat grain breakage and cleaning efficiency by Vogal Head Plant Thresher. Detail of treatment and their results has been presented in presented in Table 3.

\section{RESULTS AND DISCUSSION}

Vogal Head Plant Thresher was modified and tested for determination of Threshing efficiency(TE), Cleaning efficiency (CE), Damage grain losses (DGL), grain losses in straw (GLS) and un-threshed grain losses (UGL) at Agricultural Engineering Workshop Department of Farm machinery and power, University of Agriculture Faisalabad.

The data were collected to study the effect of three wheat varieties $\left(V_{1}=\right.$ Sahar-2006, $V_{2}=$ Shafaq-2006, $V_{3}=$ Lasani-2008), three different cylinder $\mathrm{rpm}\left(\mathrm{S}_{1}=1600 \mathrm{rpm}, \mathrm{S}_{2}=1700\right.$ $\mathrm{rpm}$ and $\left.S_{3}=1800 \mathrm{rpm}\right)$ at three different feed rates $\left(\mathrm{FR}_{1}=200 \mathrm{~kg} / \mathrm{h}, F R_{2}=250 \mathrm{~kg} / \mathrm{h}\right.$, $\mathrm{FR}_{3}=300 \mathrm{~kg} / \mathrm{h}$ ) on the machine efficiency and crop recovery. The collected data were statistically analyzed with the help of SAS system on personal computer. The statistically analyzed results of effects of variety (V), Thresher speed (S) and feed rate (FR) on machine threshing efficiency (TE), machine cleaning efficiency (CE), damage grain losses (DGL), grain loss in straw (GLS), un-threshed grain losses (UGL) and total grain losses (TGL) have been presented and discussed as following. 
Effect of machine and crop parameters on threshing efficiency, Un-Threshed grains, Damage Grain Losses, Cleaning Efficiency, Grain Loss in Straw and Total grain losses. The statistically analyzed results for the effect of wheat varieties, cylinder speed and feed rate on the threshing efficiency Un-Threshed grains, Damage Grain Losses, Cleaning Efficiency, Grain Loss in Straw and Total grain losses of Vogal head wheat thresher has been presented in table 3 . The results indicate that greatest threshing efficiency and cleaning efficiency was observed for variety $V_{1}$ (Sahar-2006). Similarly, it is also clear from the table that minimum un-threshed grain, damage grain losses and grain loss in straw were observed for variety $V_{1}$. It is therefore recommended that if a farmer is going to cultivate the wheat crop, he should cultivate variety $V_{1}$ (Sahar-2006) for getting more wheat threshing efficiency, cleaning efficiency and minimum damage of grains because variety $V_{1}$ (Sahar-2006) was better for threshing by thresher. It can safely be concluded that variety $V_{1}$ is more brittle and inelastic than the other two varieties which helped in grain detachment from wheat plant and ultimately increased threshing efficiency, cleaning efficiency and the lowest grain damage and total grain losses.

Similarly, the greatest threshing efficiency and cleaning efficiency of wheat thresher was observed at speed level $S_{3}(1800 \mathrm{rpm})$. It is also clear from the table that minimum unthreshed grains, damage grain losses, grain loss in straw and total grain loss was observed at speed level S3 $(1800 \mathrm{rpm})$. The speed $S_{3}(1800 \mathrm{rpm})$ could be the best for detaching/separating grains from straw that increased threshing efficiency and threshing efficiency due to which minimum un-threshed grains, damage grain losses, grain loss in straw and total grain loss was observed at speed level S3 (1800 rpm). It could therefore, be recommended that if a farmer have to thresh the wheat for getting greatest threshing efficiency, cleaning efficiency and minimum losses of grain speed level $S_{3}(1800 \mathrm{rpm})$ would be better for threshing.

This was due to the reason that the grain needed certain force to be detached from the ear head. Since the impact and rubbing forces imparted by rotating cylinder to the grain varied with speed, therefore, at a particular speed only a fraction of grains present in the ear head would be threshed and this fraction of threshed grain increased at higher speeds. When the force exerted by cylinder on ear-head just equaled the maximum force needed to thresh all grain, the threshing efficiency became almost constant and approached $100 \%$. At a cylinder speeds of $1800 \mathrm{rpm}$ where the total losses were $3.106 \%$ the threshing efficiency was found to be $93.05 \%$.

The statistically analyzed results show that the greatest threshing efficiency, cleaning efficiency, and minimum un-threshed grains, damage grain losses, grain loss in straw and total grain loss was observed of wheat thresher at feed rate $\mathrm{FR}_{1}(200 \mathrm{~kg} / \mathrm{h})$. The table depicts that with the increase in feed rate, there was decrease in the threshing efficiency of wheat thresher. The lower threshing efficiency at higher feed rate could be due to more cushioning effect of more material that hindered in grain separation.

Table 3 - Effect of machine and crop parameters on threshing efficiency, Un-Threshed grains, Damage Grain Losses, Cleaning Efficiency, Grain Loss in Straw and Total grain losses

\begin{tabular}{|c|c|c|c|c|c|c|c|}
\hline \multicolumn{2}{|c|}{ Parameter } & $\begin{array}{l}\text { Threshing } \\
\text { Efficiency }\end{array}$ & $\begin{array}{l}\text { Un-threshed } \\
\text { Grain Losses }\end{array}$ & $\begin{array}{c}\text { Damage } \\
\text { Grain Losses } \\
(\%)\end{array}$ & $\begin{array}{c}\text { Cleaning } \\
\text { Efficiency } \\
(\%)\end{array}$ & $\begin{array}{l}\text { Grain Losses } \\
\text { in Straw (\%) }\end{array}$ & $\begin{array}{l}\text { Total Grain } \\
\text { Losses (\%) }\end{array}$ \\
\hline \multirow{3}{*}{$\begin{array}{l}\text { Wheat } \\
\text { varieties }\end{array}$} & $V_{1}$ & $92.94^{\mathrm{a}^{x}}$ & $0.81^{a^{x}}$ & $0.81^{\mathrm{a}^{x}}$ & $95.05^{\mathrm{a}^{\star}}$ & $0.6641^{a^{x}}$ & $3.189^{\mathrm{a}^{\mathrm{x}}}$ \\
\hline & $\mathrm{V}_{2}$ & $92.83^{\mathrm{a}}$ & $1.65^{a}$ & $0.86^{a}$ & $94.79^{b}$ & $0.7233^{b}$ & $3.256^{\mathrm{a}}$ \\
\hline & $\mathrm{V}_{3}$ & $92.81^{a}$ & $1.72^{\mathrm{a}}$ & $0.87^{a}$ & $94.71^{a}$ & $0.9089^{a}$ & $3.296^{\mathrm{a}}$ \\
\hline \multirow{3}{*}{$\begin{array}{l}\text { Cylinder } \\
\text { Speed } \\
\text { (rpm) }\end{array}$} & $\mathrm{S}_{1}$ & $92.617^{b^{n}}$ & $1.714^{\mathrm{a}}$ & $0.8711^{a^{n}}$ & $94.602^{a^{x}}$ & $0.8211^{\mathrm{a}^{x}}$ & $3.384^{\mathrm{a}^{\mathrm{x}}}$ \\
\hline & $\mathrm{S}_{2}$ & $92.908^{\mathrm{ab}}$ & $1.636^{\mathrm{b}}$ & $0.8474^{a}$ & $94.908^{a}$ & $0.7855^{\mathrm{b}}$ & $3.252^{\mathrm{a}}$ \\
\hline & $\mathrm{S}_{3}$ & $93.052^{a}$ & $1.546^{\mathrm{b}}$ & $0.83^{a}$ & $94.984^{b}$ & $0.6896^{\mathrm{b}}$ & $3.106^{\mathrm{b}}$ \\
\hline \multirow{3}{*}{$\begin{array}{l}\text { Feed rate } \\
\quad(\mathrm{kg} / \mathrm{h})\end{array}$} & $\mathrm{FR}_{1}$ & $93.048^{\mathrm{a}^{x}}$ & $1.525^{\mathrm{a}^{n}}$ & $0.815^{a^{n}}$ & $94.95^{a^{x}}$ & $0.6807^{b^{n}}$ & $3.21^{\mathrm{a}^{x}}$ \\
\hline & $\mathrm{FR}_{2}$ & $92.816^{\mathrm{b}}$ & $1.675^{\mathrm{a}}$ & $0.857^{\mathrm{a}}$ & $94.83^{a}$ & $0.7889^{b}$ & $3.23^{a}$ \\
\hline & $\mathrm{FR}_{3}$ & $92.714^{\mathrm{b}}$ & $1.696^{\mathrm{b}}$ & $0.877^{\mathrm{a}}$ & $94.71^{a}$ & $0.8267^{a}$ & $3.3^{a}$ \\
\hline
\end{tabular}


Superscripts show column wise and row wise comparison respectively; Same alphabets a, b, c etc indicate means in each column followed by the same letter are not significantly different at $5 \%$ probability level $V_{1}=$ Sahar-2006, $V_{2}=$ Shafaq-2006, $V_{3}=$ Lasani-2008, $S_{1}=1600 \mathrm{rpm}, S_{2}=1700 \mathrm{rpm}$ and $S_{3}=1800 \mathrm{rpm}$ and $F_{R_{1}}=200 \mathrm{~kg} / \mathrm{h}$, $\mathrm{FR}_{2}=250 \mathrm{~kg} / \mathrm{h}, \mathrm{FR}_{3}=300 \mathrm{~kg} / \mathrm{h}$

Model of threshing efficiency, cleaning efficiency and total grain losses for machine parameters. The data of threshing efficiency of Vogal head wheat thresher for wheat at various combinations of machine and crop parameters i.e. crop variety $(\mathrm{V})$, cylinder speed $(\mathrm{S}, \mathrm{rpm})$ and feed rate (FR, $\mathrm{kg} / \mathrm{h}$ ) were recorded. A covariate (Regression analysis) using statistical package, PROG GLM (General Linear Model) procedure of the SAS was employed to study the effect of different machine and crop parameters. The covariate analysis yielded the model which is shown in Eq.1 for the threshing index in term of crop variety (V), cylinder speed $(\mathrm{S}, \mathrm{rpm})$ and feed rate $(\mathrm{FR}, \mathrm{kg} / \mathrm{h})$ having a coefficient of correlation of 0.537 . The equation 1 indicates that speed, feed rate contributed $31 \%$ and $18.5 \%$ respectively while the interaction of $\mathrm{V}^{*} \mathrm{~S}, \mathrm{~V}^{2 *} \mathrm{~S}$ and $\mathrm{V}^{*} \mathrm{~S}^{*} \mathrm{FR}^{2}$ contribute $30.50 \%, 11.5 \%$ and $7.96 \%$ respectively. It was confirmed that the speed and feed rate were important machine parameter toward machine threshing efficiency, while their interaction had played a moderate role in threshing efficiency.

The covariate analysis yielded the model (Eq.2) for the cleaning index in term of crop variety $(\mathrm{V})$, cylinder speed $(\mathrm{S}, \mathrm{rpm})$ and feed rate $(\mathrm{FR}, \mathrm{kg} / \mathrm{h})$ having a coefficient of correlation of 0.319 . The equation 2 indicated that variety; speed and feed rate contributed $30.46 \%, 50 \%$ and $19.54 \%$ respectively while the interaction of variety, speed and feed rate had non-significant effect. It was confirmed that the variety, speed and feed rate were important parameter toward machine cleaning efficiency, while their interaction had play a fewer role in cleaning efficiency.

$$
\begin{aligned}
& T E=83.44+8.008^{*} S+2.11^{*} F R-4.21^{*} V^{*} S-0.03^{*} V^{2 *} S+2.09^{*} V * S * F R^{2} \\
& C E=91.64+1.76^{*} V+3.23^{*} S-0.29^{*} F R \\
& T G L=-7.823+19.86^{*} S+5.67^{*} V^{2} S-1.69^{*} V^{2}{ }^{*} S^{2}
\end{aligned}
$$

The covariate analysis yielded the following model for the total grain losses index in term of crop variety (V), cylinder speed (S, rpm) and feed rate (FR, $\mathrm{kg} / \mathrm{h}$ ) having a coefficient of correlation of 0.48 . The equation (Eq.3) indicates that cylinder speed contributed $57.32 \%$ while the interaction of $\mathrm{V}^{2 *} \mathrm{~S}$ and $\mathrm{V}^{2 *} \mathrm{~S}^{2}$ contribute $31.68 \%$ and $11 \%$ respectively to the total gain losses index. It was confirmed that the variety and speed were important parameters toward machine total grain losses, while interaction of other parameter i.e. feed rate and speed had play a moderate role in total grain losses.

\section{CONCLUSION}

Following important conclusions can be drawn from the whole discussion:

The threshing efficiency (TE) was found greatest for variety $V_{1}$ (Sahar-2006), speed $S_{3}$ (1800 rpm) and feed rate $\mathrm{FR}_{1}(200 \mathrm{~kg} / \mathrm{h})$;

The un-threshed grain losses (UGL) were found minimum for variety $V_{1}$ (Sahar-2006), speed $\mathrm{S}_{3}(1800 \mathrm{rpm})$ and feed rate $\mathrm{FR}_{1}(200 \mathrm{~kg} / \mathrm{h})$;

The damage grain losses (DGL) were found minimum for variety $V_{1}$ (Sahar-2006), speed $\mathrm{S}_{3}(1800 \mathrm{rpm})$ and feed rate $\mathrm{FR}_{1}(200 \mathrm{~kg} / \mathrm{h})$;

The cleaning efficiency (CE) was noticed as greatest for variety $V_{1}$ (Sahar-2006), speed $\mathrm{S}_{3}(1800 \mathrm{rpm})$ and feed rate $\mathrm{FR}_{1}(200 \mathrm{~kg} / \mathrm{h})$;

The grain losses in straw (GLS) were found minimum variety $V_{1}$ (Sahar-2006), speed $\mathrm{S}_{3}(1800 \mathrm{rpm})$ and feed rate $\mathrm{FR}_{1}(200 \mathrm{~kg} / \mathrm{h}) ;$

The total grain losses (TGL) were found minimum variety $V_{1}$ (Sahar-2006), speed $S_{3}$ (1800 rpm) and feed rate $\mathrm{FR}_{1}(200 \mathrm{~kg} / \mathrm{h})$;

The cylinder speed $S_{3}(1800 \mathrm{rpm})$ and feed rate $\mathrm{FR}_{1}(200 \mathrm{~kg} / \mathrm{h})$ was found most appropriate conditions for the operation of Vogal head plant thresher. 


\section{REFERENCES}

1. Ahmad, N. 2004. Country report: Pakistan. Presented at third session of technical advisory committee of the Asian and Pacific Centre for Agricultural Engineering and Machinery held at Hanoi, Vietnam on December 13-14.

2. Behera B K, Dash S K, Das D K. Development and testing of a power operated wheat thresher. Agricultural Mechanization in Asia, Africa and Latin America (AMA), 1990; 21(4): $15-21$

3. Chaudhry, M.A. 1979. Wheat losses at the threshing and winnowing stages. J. Agric. Mech. Asia Africa and Latin America 10:67-70.

4. Ghaly A E. A stationary threshing machine: Design construction and performance evaluation. Agricultural Mechanization in Asia, Africa and Latin America (AMA), 1985; 16(3): $19-30$.

5. Joshi H C. Design and selection of thresher parameter and componments. Agricultural Mechanization in Asia, Africa and Latin America (AMA), 1981; 21(3): 29-32.

6. Klenin N I, Popov I F, Sakun V A. Agricultural machines. Amerind publishing company. Pvt. Ltd., New Delhi, 1986

7. Mahmoud, M. A. and M. A. Moheb, El-Sharabasy and M.A. Khattab. 2007. Development of feeding device in a turkish threshing machine. Misr J.of Agri. Engg. 24(2):235-258.

8. Mishram, T. N. and K. Desta. 1990. Development and Performance Evaluation of a Sorghum Thresher. J. of Agric. Mechanization in Asia, Africa and Latin America. 21(3):33-37.

9. Nkama, I. 1992. Local Rice Processingg. Paper presented at the monthly Tech. Review Meeting for Taraba ADP, Adamawa, Nigeria.

10. Olaoye $\mathrm{J} \mathrm{O}$. An analytical modeling of the performance of tooth peg grain crop thresher. PhD Dissertation. Nigeria: Department of Agricultural Engineering and Biosystems, University of llorin, 2004.

11. Olaoye J O, Oni K C. Some physical and mechanical properties of selected grain crops. In: Proceedings of the 2nd International Conference \& 23rd Annual General Meeting of the Nigerian Institution of Agricultural Engineers (A division of NSE), 2001; 23: 315-329

12. Olaoye, $\mathrm{J} O$. Evaluation of the physical characteristics of a castor nut in Nigeria. In: Proceedings of the 2nd National Engineering conference. A conference organized by the School of Engineering, Kaduna Polytechnic, Kaduna, Nigeria, 1998; 5(1): 13 -20.

13. Sexana, J.B., B.S, Sirohi, and A.K. Sharma, 1971.cPower requirements of Ludhiana type threshers. J. Agric. Engg. 8:35-43.

14. Singh, M.P. and S. Bachchan, 1992, Performance evaluation of a pigeon pea thresher. Proceedings of International Agri. Engg. Conference, Bangkok, Thailand, pp.403-409.

15. Singh K N, Singh B Effect of crop and machine parameters on threshing effectiveness and seed quality of soybean, Journal of Agricultural Engineers Research (JAER), 1981; 17: $23-28$

16. Song, H.and J.B. Litchfield, 1991. Predicting method of terminal velocity for grains trans. ASAE, 34(1): 225-231.

17. Ukatua, A.C. 2006. A modified threshing unit for soya beans. Department of agricultural engineering, University of agriculture, PMB 2240, Abeokuta, ogum state, Nigeria. 95(05): 371-377

18. Yasin M. and A. Ansari 1981. Test and Evaluation (necessary components of farm machinery). The journal of society of Agricultural Engineering, 8-12. 